\title{
AN ASSESSMENT OF THE CONCEPTUAL LINKAGES BETWEEN THE QUALITATIVE CHARACTERISTICS OF USEFUL FINANCIAL INFORMATION AND ETHICAL BEHAVIOR WITHIN INFORMAL INSTITUTIONS
}

\author{
Ebiaghan Orits Frank* \\ Faculty of the Social Sciences, Delta State University, Abraka, Nigeria
}

This research is aimed at assessing the conceptual linkages between the qualitative characteristics of useful financial information defined by the International Accounting Standards Board (IASB) and ethical behavior within informal institutions. Derrida's deconstruction theory was employed to carry out a diagnostic content analysis of the chapter two of the IASB's 2018 financial reporting conceptual framework. The findings arising from the study reveal salient conceptual linkages between the fundamental (primary) and enhancing (secondary) qualitative characteristics and biblical ethical constructs, such as objectivity, equity/fairness, accuracy, neutrality, humility, trust, honesty, responsibility, open accountability, public trust, discipline and diligence. Consequently, the study recommends the inclusion and teaching of these ethical constructs in the curricula of tertiary and professional accountancy programs so as to churn out intellectually sound and morally balanced accounting professionals, who will prepare and present decision-useful financial statements with a high sense of moral and ethical responsibility.

Keywords: accounting information, The Bible, ethical behavior, IASB2018 Conceptual Framework, qualitative characteristics

JEL Classification: M400, M410

\section{INTRODUCTION}

Published financial statements remain the most credible source of information on the financial health of a business entity, the accounting information inherent therein being used by various stakeholders in

* Correspondence to: E. O. Frank, Faculty of the Social Sciences, Delta State University, Abraka, Nigeria;

e-mail:oritz001@yahoo.com making investment decisions. In financial statements, data about the financial position, performance and changes in the financial position principally communicated through a statement of the financial position, a statement of changes in equity, a statement of comprehensive income and a cash flow statement (Ebiaghan, 2018, 35) are presented. However, in the course of preparing and presenting corporate reports, accounting regulatory bodies offer accountants a latitude to apply discretionary judgments in adopting 
a suitable accounting basis, which efficiently reflects the firm's accounting policy, reporting obligations, operations and disclosure requirements. It has been observed oftentimes that, in a bid to select a method from competing diverse approaches in preparing and presenting financial transactions and events, managers exploit this opportunity so as to engage in creative accounting or earnings management, which involves a willful misrepresentation and manipulation of accounting information intended to create a false reality, thereby deceiving the users of financial statements (Yahaya, 2014). This unethical behavior majorly stems from moral bankruptcy and a dearth of virtue. It is imperative to note that honest character traits are lacking in today's corporate world, as corruption, greed and malfeasance in the workplace have become commonplace. The immoral and unethical abuse of office have become rampant among business executives, who exploit their position for filthy lucre sake in a bid to gratify their selfish desires, thereby occasioning several corporate scandals, like Enron, WorldCom, Lehman Brothers and so on (Ezeani, Ogbonna, Ezemoyih \& Okonye, 2012, 5).

In order to preserve financial information integrity, the IASB issued the latest financial reporting conceptual framework in 2018, asserting the fact that financial statements are mainly aimed at providing decision-useful information to creditors, potential and present investors, as well as other stakeholders, when making credit, investment and allied resource allocation decisions, helping them assess the timing and amounts of the enterprise's prospective cash inflows and outflows. Furthermore, the chapter two of the framework specifies two principal threshold qualitative characteristics that these pieces of information must have in order to enhance decisionmaking, namely:

- fundamental (primary) characteristics, which include relevance and representational faithfulness, in addition to

- enhancing (secondary) characteristics, which comprise verifiability, timeliness, understandability and comparability.

\section{THE RATIONALE FOR THE STUDY}

Consequently, upon an exhaustive review of the extant literature on notable accounting scandals, like Enron, Tyco, WorldCom, HealthSouth and Xerox in the U.S, and the liquidation of the African International Bank (AIB), Cadbury and African Petroleum (AP) in Nigeria, a common observation is that financial statement preparers quite often flagrantly circumvent regulatory provisions and willfully manipulate accounting numbers, thus making nonsense of these qualitative characteristics of useful financial information. These unethical practices adversely affect the reliability and truthfulness of the financial information used to make investment decisions with dire implications for profitability and corporate sustainability (Odia \& Ogiedu, 2013, 45; Yahaya, 2014).

Particularly, these unethical practices have been thriving due to moral depravation and an utter disregard for ethical character traits in today's corporate world. Therefore, this research is aimed at assessing the chapter two of the IASB's 2018 qualitative characteristics of useful financial information and attempting to establish their conceptual linkage with ethical behavior within informal institutions, coupled with how their application to daily living may help accounting professionals (financial statement preparers) eschew fraudulent practices. The methodology for this research is based on Derrida's deconstruction theory.

Following this Introduction and Rationale for the study, the following sections of the paper are structured as follows: In Section 2, the extant literature and conceptual clarifications on the IASB's Conceptual Framework and biblical virtues are discussed. In Section 3, Derrida's deconstruction theory is extensively discussed as the research methodology adopted in order to establish conceptual linkages between the qualitative characteristics of useful financial information and biblical virtues. In Section 4, the research findings are exhaustively discussed and a model depicting the conceptual linkage is presented. In Section 5, the conclusion is given. 


\section{LITERATURE REVIEW}

\section{The significance and benefits of the global accounting standards harmonization}

The idea for the harmonization of global accounting standards arose from a quest for the synchronization of accounting practice throughout the European Union. However, the economic gains of convergence promptly encouraged the notion worldwide. Notably, the first set of the issued standards (originally referred to as the International Accounting Standards (IAS)) were released circa 1973 and 2001 by the International Accounting Standards Committee (IASC). On 1st April 2001, the newly constituted Board of IASB replaced the IASC, thus assuming responsibility for setting the International Accounting Standards. At its inaugural convention, the newfangled Board implemented the existing IAS and Standing Interpretations Committee standards (SICs). The IASB sustained the continuous development of the standards referring to the new standards as the International Financial Reporting Standards (IFRS). These sets of standards are fashioned as a mutual universal language for commercial transactions to aid in the understandability and comparability of company accounts across transnational boundaries. They are a fallout of rising international trade and shareholding principally important for multinational companies. Convergence to the globally recognized accounting standards (IFRS) enables comparability between companies operating in different countries. Therefore, the global accounting standards are aimed at removing restrictions to capital flows and expanding investment in markets. Equally, IFRS convergence promotes industrial growth, as complying with their provisions engenders investors' confidence and reduces the cost of raising foreign capital. The IFRS released by the IASB are currently being accepted and recognized as the foremost accounting information reporting standards globally. Presently, over a hundred nations are authorizing or mandating the IFRS implementation within their territories. It has become the most common and the most widely accepted financial reporting model throughout the world, given the fact that the countries of the Eurozone, New Zealand, Russia and Australia have instituted the legal frameworks that currently authorize the IFRS implementation within their respective jurisdictions. Equally, the Securities Exchange Commission (SEC) of the United States of America (USA) has endorsed the IFRS implementation without reconciling the United States Generally Accepted Accounting Principles (USGAAP) in the corporate reports prepared by foreign private enterprises, thereby availing foreign private enterprises discretionary privilege to choose between the IFRS and the USGAAP. The SEC suggested that USA enterprises should commence reporting under the IFRS from 2014, whereas a full conversion took place in 2016, contingent upon an entity's size, which action virtually encouraged the entire globe to one distinct, uniform accounting policy, i.e. the IFRS (Samir, 2003, 25; Srkant, 2005, 18; Olanrewaju, 2012, 13). Studies on the importance of transnational accounting practices have increased over years in response to the satisfaction of investors' demands, and expedite international business practices where there is a need to consider the fact that international accounting convergence is of a significant interest for investors, capital market regulators, governments and diverse stakeholders who utilize the accounting information of public enterprises, thus accentuating the strategic role of accounting as a fiscal tool for several economic agents. The advantages of such global accounting convergence rests on its ability to lessen adverse effects emanating from different accounting practices in diverse countries (Hati \& Rakshit, 2002, 34; Bala \& Ibrahim, 2017, 75). Hence, the introduction of the IFRS for listed companies in many countries could globally be regarded as a radical regulatory innovation to the history and practice of the accountancy profession.

In their paper espousing the significance of the firstrate accounting standards, H. Daske and H. Gunther $(2006,464)$ emphasized the fact that the accounting standards harmonization was germane to the delivering of the reliable information rooted in honest financial reporting. He enumerates the three major 
criteria the international standards have to have in order to be accepted, namely:

- The standards have to incorporate the core sets of the accounting declarations that constitute a generally accepted and comprehensive accounting basis.

- The standards should be of a high quality and have to guarantee transparency and comparability by providing full disclosure. Shareholders should be capable of implicitly analyzing performance across financial years and companies.

- The standards have to be meticulously interpreted and globally enforced by regulators and auditors by their insisting on the painstaking application and interpretation of those standards. If not so, the transparency and comparability objective of the mutual standards will be defeated.

\section{The IASB conceptual framework}

The IASB Conceptual Framework for Financial Reporting can be described as the main document that stipulates the concepts and objectives which guide the presentation and preparation of financial reports. The framework is a comprehensive structure of the concepts that emanate from an objective, while the objective recognizes the financial reporting rationale. The concepts offer a direction towards the recognition of the limits of financial reporting, a choice of transactions and economic activities to be recognized and measured (or disclosed), in addition to the formats for their summarization and reporting (FASB, 2006, 2-5; 2010, 3)

The core purpose of the Framework includes (IASB, 2018):

- assistance in reviewing the existing standards and the formulation of future IFRS by spelling out the fundamental concepts;

- fostering the synchronization of accounting standards and regulation by decreasing the number of allowable marginal accounting treatments;
- assistance for the preparers of published financial statements applying the IFRS, especially with regards to the handling of the business events for which an accounting standard is yet to be formulated.

Its precursor, the Framework for the Preparation and Presentation of Financial Statements, was issued in 1989. While, on the one hand, the IASB issued an improved version in 2010, which was referred to as the Conceptual Framework for Financial Reporting, this version was notably quite incomplete given the fact that a few chapters and concepts were omitted, the latest and the most comprehensive Framework issued in 2018, on the other, includes a total of eight chapters itemized below:

- Chapter One: The Objective of General-Purpose Financial Reporting

- Chapter Two: The Qualitative Characteristics of Useful Financial Information

- Chapter Three: Financial Statements and the Reporting Entity

- Chapter Four: The Elements of Financial Statements

- Chapter Five: Recognition and Derecognition

- Chapter Six: Measurement

- Chapter Seven: Presentation and Disclosure

- Chapter Eight: The Concepts of Capital and Capital Maintenance

Bearing in mind the fact that this research is principally focused on assessing the conceptual linkages between the Qualitative characteristics of useful financial information and ethical conduct in informal institutions, chapter two of the conceptual framework constitutes the major basis of analysis hence an exhaustive discussion of its attributes is necessary to enrich our understanding of the background of the study. 


\section{The qualitative characteristics of useful financial information}

Qualitative characteristics refer to the attributes necessary for accounting information to serve as the key supporting function in the usefulness of decisions. These are the characteristics and qualities which the preparers of financial statements have to imbibe with a view of making accounting information worthwhile for users. According to the FASB $(2010,15)$, reported accounting information aimed at facilitating investment decisions should have certain features or normative standards, the informational attributes of decision-useful financial statements recognized by the FASB in its Concept No. 2 Qualitative Characteristics of Accounting Information, and slightly modified and accepted in the IASB Framework. Chapter Two, entitled the Qualitative Characteristics of Useful Financial Information, is presented in Figure 1.

The chapter two of the IASB Conceptual Framework identifies the two kinds of the qualitative characteristics required for financial information to be decision-useful:
- fundamental (primary), and

- enhancing (secondary).

The fundamental (primary) qualitative characteristics of financial information include the following:

- relevance, which refers to the ability of financial information to significantly influence users' economic decisions. Financial information is deemed to be relevant when it has a confirmatory value, a predictive value, or both these values. Materiality is akin to relevance.

- faithful representation, which implies that information is deemed to be faithfully represented when being error-free, complete and neutral.

- The enhancing (secondary) qualitative characteristics of financial information include the following:

- comparability, which implies the fact that information should be similar between different entities or different time periods;

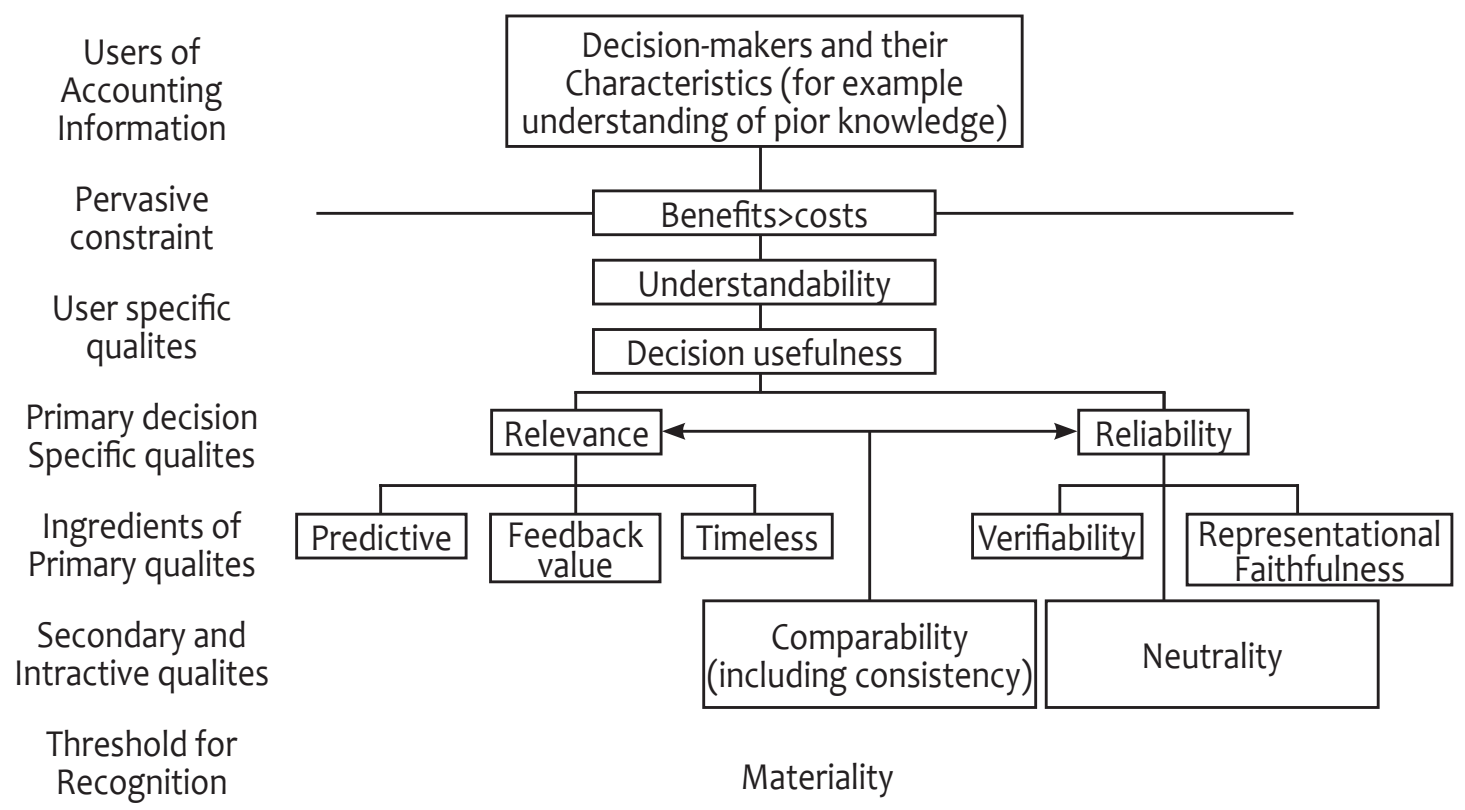

Figure 1 A Hierarchy of Accounting Qualities 
- verifiability, which implies that knowledgeable and independent witnesses should be capable of authenticating such information;

- timeliness, which connotes the availability of information as and when required in order to influence the user's economic decisions, and

- understandability, which implies that information should concisely and clearly be categorized and presented.

\section{Differences between FASB 2006 and IASB 2018 Conceptual Framework with respect to the qualitative characteristics of accounting information}

Based upon the discussion in the preceding section, it can be observed that, although the FASB 2006, SFAC No. 2 (as depicted in Figure 1) and the chapter two of the IASB 2018 Conceptual Framework are primarily focused on the qualitative characteristics of accounting information, there are obvious differences in their respective contents with respect to the elements of financial statements and the primary or fundamental qualities, while the contents of the IASB 2018 Conceptual Framework consist of relevance and faithful representation, and those of the FASB 2006 consist of relevance and reliability. Observed from the point of view of the requirements of the fundamental qualities, differences are equally present. In IASB
2018, relevance consists of the predictive value and the confirmatory value, and in FASB 2006, it consists of the predictive value, the feedback value and timeliness. Additionally, IASB 2018 faithful representation consists of completeness, neutrality and the absence of an error. In FASB 2006, however, it is named reliability and consists of verifiability, representational faithfulness and neutrality. Perceived from the point of view of the enhancing qualities, it is also different. In IASB, it consists of comparability, verifiability, timeliness and understandability. Remarkably, the IASB 2018 Financial Reporting Conceptual Framework represents a comprehensive and updated document aimed at enhancing the qualitative characteristics of financial statements, bearing in mind the fact that the same incorporates an innovation regarding the interpretation of the notion of fair reporting and presentation, which connotes the essence of decision-useful financial statements.

The differences between the FASB 2006 and IASB 2018 conceptual frameworks is are described in Table 1.

\section{The nexus between biblical virtues and ethical behavior constructs}

Virtue is defined by Webster's dictionary as "conformity to the standard of right: morality. Moral excellence; beneficial quality, strength and courage, and a capacity to act: potency". Viewing this definition from a biblical standpoint, R. J. Krejcir (1991,

Table 1 The differences between FASB 2006 and IASB 2018 in the qualitative characteristics of accounting information

\begin{tabular}{|c|c|c|c|c|}
\hline \multirow{2}{*}{$\begin{array}{l}\text { Description } \\
\text { Primary/fundamental } \\
\text { quality }\end{array}$} & \multicolumn{2}{|c|}{$\begin{array}{l}\text { FASB qualitative characteristics of accounting } \\
\text { information }\end{array}$} & \multicolumn{2}{|c|}{$\begin{array}{l}\text { IASB qualitative characteristics of useful } \\
\text { financial information }\end{array}$} \\
\hline & Relevance & Reliability & Relevance & $\begin{array}{l}\text { Faithful } \\
\text { representation }\end{array}$ \\
\hline $\begin{array}{l}\text { Ingredients of } \\
\text { fundamental qualities }\end{array}$ & $\begin{array}{l}\text { - Predictive value } \\
\text { - Feedback value } \\
\text { - Timeliness }\end{array}$ & $\begin{array}{l}\text { - Verifiability } \\
\text { - Representational } \\
\text { faithfulness } \\
\text { - Neutrality }\end{array}$ & $\begin{array}{l}\text { - Predictive value } \\
\text { - Feedback value }\end{array}$ & $\begin{array}{l}\text { - Completeness } \\
\text { - Neutrality } \\
\text { - Error-free }\end{array}$ \\
\hline Enhancing qualities & \multicolumn{2}{|c|}{ Comparability, consistency } & \multicolumn{2}{|c|}{$\begin{array}{l}\text { Comparability, verifiability, timeliness, } \\
\text { understandability }\end{array}$} \\
\hline
\end{tabular}

Source: Kieso, Weygandt \& Warfield, 2007; Kieso, Weygandt \& Warfield, 2011 
2001) defines virtue as the tendency to be blameless, prompted by a deliberate will to act right from the point of the word of God, in addition to personal responsibility. It involves compassion, honesty, integrity and endearment, which epitomizes the essence of the biblical character (modesty, strength, right standards, purity and courage, all complete in excellence). He notes that virtue is acquired through faith in and obedience to Christ, which occur in true repentance. Furthermore, by espousing the inimitable positive effects of constant meditation on biblical virtues, Apostle Paul summarily concludes in the Philippians Chapter 4 Verse 8: "Finally, brethren, whatever things are true, whatever things are noble, whatever things are just, whatever things are pure, whatever things are lovely, whatever things are of good report, if there is any virtue and if there is anything praiseworthy - meditate on these things." (The Holy Bible, KJV). Ostensibly, the biblical definition of virtue infers the attitudes that are just (fair), noble, pure (holy living), true (the truth), lovely (as Christ is), and the character of good report (noble acts towards God and Man). However, as already mentioned herein, these ethical character traits are scarce in today's corporate world as corruption, greed and malfeasance in the workplace have become rampant, immoral and the unethical abuse of office has become commonplace amongst business executives in an effort to mitigate their untoward impact on businesses. The government on its part has enacted several legislations, such as the 2002 Sarbanes-Oxley Act, which was a direct reaction to the Enron accounting scandal in the United States of America, so as to assist in shielding shareholders from fraudulent financial reporting by companies.

\section{The theoretical framework}

This study is anchored in the agency theory of accounting research, which underscores the stewardship reporting responsibility of managers (agents) to the shareholders (owners) of the enterprise via corporate reports geared towards proffering valuedriven, reliable and relevant accounting information suitable for financial analysis and investment decisions. This theory presupposes that principals (shareholders) are those who own the company, whereas agents (managers) are those controlling it. However, this separation of the company ownership from company control will create agency problems, whereas a conflict of interest might arise in firms in situations when managers' (agents') personal interests override their obligations to comply with the principalagent contract stipulating the maximization of shareholders' wealth (Sheikh, Khan, Iqbal \& Ahmed, 2012, 243). However, while financiers (principals) need managers' specialized skills to create returns on invested capital, management ultimately depends on principals for the financial structuring of the business they supervise, thus needing an approval from them. Creating complexities in the agency relationship in that manner, among which, foremost, is the fact that the management is more informed about corporate numbers than the principals (information asymmetry), this insider information might be fraudulently exploited, which invariably manifests in unethical and criminal conduct, which occasioned several accounting scandals involving financial statement manipulation (earnings management/ creative accounting) by the trustworthy executives of corporate entities, as was the case in the Enron, WorldCom and Lehman Brothers corporate scandals.

\section{RESEARCH METHODOLOGY}

In this research, Derrida's deconstruction theory was employed, adapted from M. Al-Fayyadl (2005) and B. Stocker (2006), so as to conduct a diagnostic content analysis of the chapter two of the IASB 2018 Financial Reporting Conceptual Framework, aimed at ascertaining the conceptual linkages between the qualitative characteristics of useful financial information and the ethical behavior constructs inherent in the Bible. According to B. Stocker (2006), deconstruction equally subsists within the "difference", but from varied perspectives, and the core of such "difference" unto differences. However, they have essentially similar content (hidden truths behind an obvious reality). However, restating Derrida's deconstruction theory, M. Al-Fayyadl (2005) espoused that deconstruction entails inducement not to gloss over the sole truth that we accept as 
true, but there are multiple realities that suit various perspectives of the thought process, the principal notion of deconstruction theory being related to repetition and otherness happening simultaneously, which implies that the truth can be perceived from another point of view or from a different perspective.

\section{RESEARCH FINDINGS AND DISCUSSIONS}

\section{Deconstructing the Biblical Origins of Contemporary Agency Theory}

Financial reporting is the primary offshoot of stewardship accounting, whose origins go back to ancient times, when landlords (present-day principals, business owners or shareholders) listened to the report or accounts of serfs/servants (presentday agents, managers, and/or directors) on how they had managed the affairs of the business in order to ascertain whether they had made a profit or a loss. That report was usually presented at the close of a voyage or trading period, usually on an annual basis (the present-day Annual General Meeting AGM). In the Bible Book of Luke 19, verses 12-22, and Matthew 25, verses 14-39, Jesus gives a parable of noble man (the landlord), who journeyed to a far country, bequeathing his goods (money) to his ten servants in order for them to trade. Upon his return, he required them to give him an account of the goods having been entrusted to them. Those who made a profit were rewarded, whereas those who made a loss were sanctioned or punished. The parable describes the ancient practices, the way how it was then, and is arguably what has metamorphosed into modern-day agency theory in accounting research, in which the owners of the entity (shareholders) entrust the control and management of their company to managers and directors, who accordingly act as agents on their behalf (Eisenhardt, 1989; Donaldson \& Davis, 1991).

Biblical ethical constructs deconstructed from the qualitative characteristics of useful financial information
As already said, the analysis of this research centers on the chapter two of the IASB 2018 Conceptual Framework on the qualitative characteristics of useful financial information.

By utilizing Derrida's deconstruction theory, the analysis of the fundamental (primary) qualitative characteristics of financial information, viz. relevance and faithful representation, as the attributes that enable accounting information suitable for decisionmaking was conducted. Relevance presupposes that accounting information should have the ability to significantly influence users' economic decisions. Financial information is considered as relevant when it has confirmatory and predictive values. (Kieso et al, 2011, 44; Ekasari, 2012a, 310)

Faithful representation implies that a piece of information is deemed to be error-free, complete and neutral, accurate, fair and objective.

Juxtaposing these attributes with biblical injunctions and admonitions from the LORD GOD, Jesus, the prophets and the apostles, there is a clear conceptual similarity. Some examples will suffice. Firstly, in his first epistle to the Corinthians Chapter 4 Verse 2, Paul the Apostle states that "moreover it is required in stewards that a man be found faithful". Equally, in Isaiah, Chapter 8 Verse 2, the prophet records how he took faithful witnesses including Uriah and Zachariah, who were both priests, to take a record of the events to come.

Furthermore, in Chapter 25, Verse 15, Deuteronomy harps on the need for standard weights and measures, by quoting as follows: "but thou shalt have a just weight, a perfect and just measure shalt thou have: that thy days may be lengthened in the land which the LORD thy GOD giveth thee", which was corroborated by the Proverbs Chapter 16 Verse 11, "a just weight and balance are the LORD's all the weights of the bag are his work". The Holy Bible (the king James's version of it). The scriptures above allow us to conveniently deduce the time-honored ethical constructs of objectivity and fairness, the accuracy of facts, and neutrality.

Secondly, the deconstruction of the biblical virtues from the enhancing (secondary) qualitative 
characteristics of financial information is discussed below:

Comparability: Comparability implies that information should be similar between different entities or different time periods, which enables the matching of accounting information pertaining to one entity with similar information in another entity. From the biblical perspective, this accounting concept teaches us humility, which ultimately spurs motivation. By comparing our business enterprise with other enterprises in the same industry, a better understanding of our current performance ratings, whether favorable or adverse (variance analysis) is obtained, thereby making necessary adjustments. This process demands humility (Ekasari, 2012b) In Peter Chapter 5 Verse 5, the Bible admonishes the younger to submit to their elders and be covered with humility because GOD resists the proud and gives more grace to the humble.

Verifiability: Verifiability is implicative of the fact that knowledgeable and independent witnesses should be capable of authenticating a piece of information, which ensues when independent observers apply the same techniques and obtain comparable results (Kieso et al, 2011). Verifiability ensures data accuracy and entrenches trust, honesty and responsibility, deconstructing this attribute from the biblical standpoint. In the first Thessalonians Chapter 2 Verse 10, Paul the Apostle says "ye are witnesses and God also, how holity and justly and unblameably we behaved ourselves among you that believe", this being further buttressed by Samuel the Prophet at the twilight of his tenure as a judge in ancient Israel, who so declared in Samuel Chapter 12 Verse 3: "Behold here I am: witness against me before the $L O R D$, and before his anointed: whose ox have I taken? Or whose ass have I taken? Or whom have I defrauded? Whom have I oppressed? Or of whose hand have I received any bribe to blind my eyes therewith? And I will restore it to you." From this scriptural declaration, it is possible to deduce open accountability and public trust.

Timeliness: Timeliness connotes the availability of information as and when required in order to influence users' economic decisions. It implies that information are made accessible to decision-makers at the right time so as to exert a significant influence on the decision-making process. Timeliness expects us to document accounting transactions as they occur. Discipline and diligence, exemplified in the Proverbs Chapter 22 Verse 29: "Seest thou a man diligent in his business? He shall stand before kings; he shall not stand before mean men," are the biblical conceptual equivalence of this virtue.

Understandability: Understandability indicates the fact that accounting information should concisely and clearly be categorized and presented so as to help users make economic decisions. Financial information should be presented in trust and honesty, and responsibly. Biblically, it is possible to deconstruct the virtue of equality from this concept, because if two entities demonstrate an equal understanding, that implies that they share the same information.

In Figure 2, a conceptual model summarizing the linkages between the IASB qualitative characteristics of useful financial information and the ethical behavior constructs inherent in the Bible are presented.

\section{CONCLUSION}

This research study is aimed at assessing the conceptual linkages between the IASB qualitative characteristics of useful financial information and ethical behavior within informal institutions by applying Derrida's deconstruction theory in order to conduct a diagnostic content analysis of the chapter two of the Framework. The obtained findings are indicative of a significant positive relationship between the qualitative characteristics of useful financial statements, as advocated in the IASB 2018 Financial Reporting Framework, on the one hand, and ethical behavior within informal institutions, on the other. The study observed the striking conceptual linkages between the fundamental and enhancing qualitative attributes and the biblical ethical behavior constructs, such as objectivity, equity/fairness, accuracy, neutrality, humility, trust, 


\section{STEWARDSHIP ACCOUNTING}

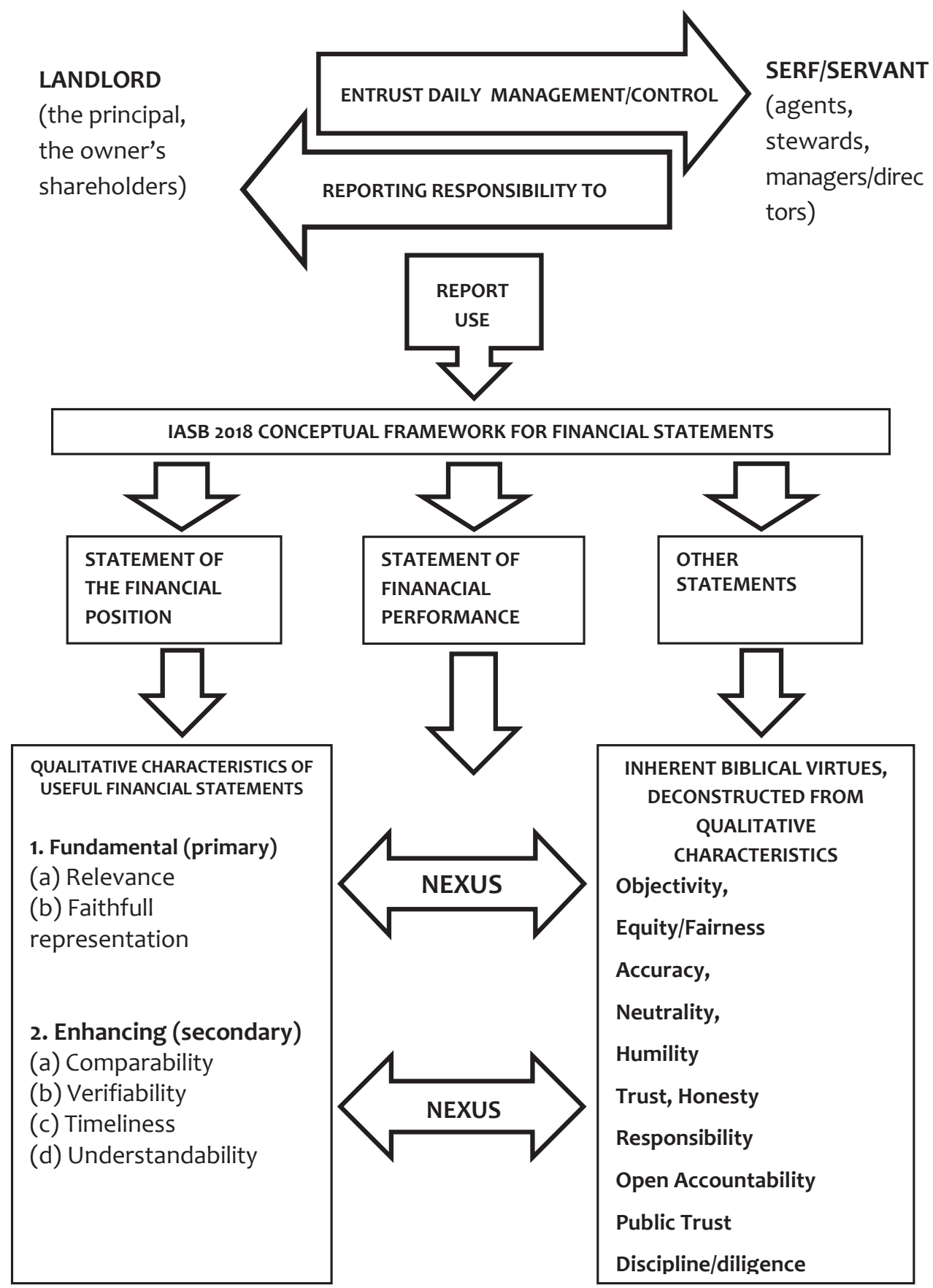

Figure 2 The conceptual model depicting the linkages between the IASB qualitative characteristics of useful financial information and ethical behavior constructs 
honesty, responsibility, open accountability, public trust, discipline and diligence. These results were corroborated by T. R. Schatzi $(2005,481)$ and K. Ekasari (2012b), who noted that the enforcement of compliance on regulatory provisions and accounting standards appeals to practitioners' will, which they can flout under the guise of applying discretionary judgements; biblical injunctions, however, appeal to practitioners' inner consciousness (the spirit/soul dimension). Hence, biblical ethical behavior forms an inimitable fragment of spiritual doctrines and norms, whose adherents are expected to conform with the beliefs, desires and emotions that ultimately culminate in desirable actions. Bearing in mind the emerging spiritual accounting philosophy, it can be concluded that there is a need for them to appeal to the moral/ ethical consciousness of the preparers of accounting information for the purpose of preserving qualitative attributes. Thus, the following is recommended:

- The accounting curriculum at both tertiary and professional levels should be re-evaluated and enriched with these biblical ethical constructs in order to inculcate them into students prior to their entering the accounting profession, which will go a long way towards instilling forthrightness and propriety in the treatment of transactions and the preparation of decision-useful financial statements.

- Beyond their inclusion in the curriculum, these biblical ethical constructs should be integrated into accounting pedagogy (the teaching-learning process), given the fact that doing so will effectively persuade students' cognitive domain to positively influence the affective domain, thereby producing intellectually sound and morally balanced accounting professionals, who will carry out duties assigned to them with a high sense of moral/ethical responsibility.

Furthermore, future research studies could be conducted so as to deconstruct the biblical/spiritual virtues from the other chapters of the IASB 2018 Financial Reporting Conceptual Framework, which will further expand the knowledge frontiers of accountancy pedagogy, promote moral/ethical consciousness amongst accounting practitioners, simultaneously significantly contributing to the deepening of the emerging spiritual accounting philosophy.

\section{REFERENCES}

Al-Fayyadl, M. (2005). Derrida. Published by LKiS Pelangi Aksara Yogyakarta.

Bala, H., \& Ibrahim, I. (2017). Monitoring characteristics and financial reporting quality of listed conglomerates firms in Nigeria. Journal of Accounting Research and Practice, 3(2), 75-93.

Daske, H., \& Gunther, H. (2006) International financial reporting standards and expert perception of disclosure quality. Abacus, 42(3/4), 461-498. doi.org/10.1111/j.14676281.2006.00211.x

Donaldson, L., \& Davis, J. H. (1991). Stewardship theory or agency theory: CEO governance and shareholder returns. Australian Journal of Management, 16(1), 49-65. doi. org/10.1177/031289629101600103

Ebiaghan, O. F. (2018). Assessment of the comparative ability of Accounting Bases in predicting future cash flows: Evidence from Nigeria. Trends Economics and Management Faculty of Business and Management, 12(32), 35-48. doi.org/10.13164/trends.2018.32.35

Eisenhardt, M., K. (1989). Agency theory: An assessment and review. The Academy of Management Review, 14(1), 5774. doi:10.2307/258191

Ekasari, K. (2012a). Portraying Accounting in spirituality perspesctive. Review of Integrative Business \& Economics Research, 1(1), 304-315.

Ekasari, K. (2012b, June). Exploring Spirituality Values in Accounting. Paper presented at the SIBR-Thammasat Conference on Interdisciplinary Business and Economics Research, Bangkok.

Ezeani, N. S., Ogbonna, M. I., Ezemoyih, E. M., \& Okonye, E. C. (2012). The effect of creative accounting on the job performance of accountants (auditors) in reporting financial statement in Nigeria. Kuwait Chapter of Arabian Journal of Business and Management Review, 1(9), 3-12. 
Financial Accounting Standards Board (FASB). (2006). Conceptual framework for reporting objectives of financial reporting and qualitative characteristics of decision-useful financial reporting information. FASB Website Terms and Conditions.

Financial Accounting Standards Board (FASB). (2008). Statement of Financial Accounting Concept No. 2, Qualitative of Accounting Information. Stamford: FASB.

Financial Accounting Standards Board (FASB). (2010). Conceptual framework for financial reporting: The objective of financial reporting and qualitative characteristics of useful financial information. FASB Website Terms and Conditions.

Hati, W. J., \& Rakshit, D. FASB Website Terms and Conditions. (2002). Integrating accounting standards -A step towards harmonization. Management accountant, ICWAI, 4(2), 32-41. Retrieved March 18, 2020, from http:// www.iasplus.com.

Kieso, D. E., Weygandt, J. J., \& Warfield, T. (2007). Intermediate Accounting. Hoboken, New Jersey: John Wiley and Sons.

Kieso, D. E., Weygandt, J. J., \& Warfield, T. (2011). Intermediate Accounting, IFRS Edition. Hoboken, New Jersey: John Wiley and Sons.

Krejcir, R. J. (1991, 2001). Why virtue is important and needed. Into Thy Word Ministries. Retrieved March 18, 2020, from www.intothyword.org.
Odia, J. O., \& Ogiedu, K. O. (2013). Corporate governance, regulatory agency and creative accounting practices in Nigeria. Mediterranean Journal of Social Sciences, 4(3), 5566. doi:10.5901/mjss.2013.v4n3p55

Olanrewaju, O. O. (2012). IFRS PAL-Handy approach (international financial reporting standards) with real life questions and answers. Lagos. Dimkem Publications.

Samir, M. S. (2003). Harmonisation of Accounting Standards. Chartered Accountant, ICAI, January, 4(2), 23-32

Srikant, S. (2005). Accounting Standards - will the World be talking same language? Chartered Accountant, ICAI, February 3(1), 15-22

Schatzki, T. R. (2005). Peripheral Vision: The sites of organizations. Organization Studies, 26(3), 465-484. doi. org/10.1177/0170840605050876

Sheikh, J. Khan, M, Iqbal, W., \& Ahmed, W. S. (2012). Examination of theoretical and empirical studies on firm's performance in relation to its board size: A study of small and medium size public firms. Journal of Management Research, 4(2), 242-254. doi:https://doi.org/10.5296/jmr. v4i2.1504

Stocker, B. (2006). Routledg Philosophy Guidebook to Derrida on Deconstruction. Abingdon, UK: Routledge.

The Holy bible, Authorized King James Version.

Yahaya, K. A. (2014, September). Creative Accounting Practices: Ethical Challenges In Nigerian corporate Environment. Paper presented at the Development Finance Conference, At Dubai.

\section{Received on $19^{\text {th }}$ March 2020, after revision, accepted for publication on $17^{\text {th }}$ August 2020. Published online on $19^{\text {th }}$ August 2020.}

Ebiaghan Orits Frank is a scholar at the Department of Accounting and Finance of the Faculty of Social Sciences of Delta State University of Abraka, Nigeria. He earned his PhD in accountancy from the Nnamdi Azikiwe University of Awka. He has broadly published and his research interest covers financial reporting, financial policy evaluation and accounting theory. 


\title{
AN ASSESSMENT OF THE CONCEPTUAL LINKAGES BETWEEN THE QUALITATIVE CHARACTERISTICS OF USEFUL FINANCIAL INFORMATION AND ETHICAL BEHAVIOR WITHIN INFORMAL INSTITUTIONS
}

\author{
Ebiaghan Orits Frank* \\ Faculty of the Social Sciences, Delta State University, Abraka, Nigeria
}

This research is aimed at assessing the conceptual linkages between the qualitative characteristics of useful financial information defined by the International Accounting Standards Board (IASB) and ethical behavior within informal institutions. Derrida's deconstruction theory was employed to carry out a diagnostic content analysis of the chapter two of the IASB's 2018 financial reporting conceptual framework. The findings arising from the study reveal salient conceptual linkages between the fundamental (primary) and enhancing (secondary) qualitative characteristics and biblical ethical constructs, such as objectivity, equity/fairness, accuracy, neutrality, humility, trust, honesty, responsibility, open accountability, public trust, discipline and diligence. Consequently, the study recommends the inclusion and teaching of these ethical constructs in the curricula of tertiary and professional accountancy programs so as to churn out intellectually sound and morally balanced accounting professionals, who will prepare and present decision-useful financial statements with a high sense of moral and ethical responsibility.

Keywords: accounting information, The Bible, ethical behavior, IASB2018 Conceptual Framework, qualitative characteristics

JEL Classification: M400, M410

\section{INTRODUCTION}

Published financial statements remain the most credible source of information on the financial health of a business entity, the accounting information inherent therein being used by various stakeholders in

* Correspondence to: E. O. Frank, Faculty of the Social Sciences, Delta State University, Abraka, Nigeria; e-mail: oritz001@yahoo.com making investment decisions. In financial statements, data about the financial position, performance and changes in the financial position principally communicated through a statement of the financial position, a statement of changes in equity, a statement of comprehensive income and a cash flow statement (Ebiaghan, 2018, 35) are presented. However, in the course of preparing and presenting corporate reports, accounting regulatory bodies offer accountants a latitude to apply discretionary judgments in adopting 
a suitable accounting basis, which efficiently reflects the firm's accounting policy, reporting obligations, operations and disclosure requirements. It has been observed oftentimes that, in a bid to select a method from competing diverse approaches in preparing and presenting financial transactions and events, managers exploit this opportunity so as to engage in creative accounting or earnings management, which involves a willful misrepresentation and manipulation of accounting information intended to create a false reality, thereby deceiving the users of financial statements (Yahaya, 2014). This unethical behavior majorly stems from moral bankruptcy and a dearth of virtue. It is imperative to note that honest character traits are lacking in today's corporate world, as corruption, greed and malfeasance in the workplace have become commonplace. The immoral and unethical abuse of office have become rampant among business executives, who exploit their position for filthy lucre sake in a bid to gratify their selfish desires, thereby occasioning several corporate scandals, like Enron, WorldCom, Lehman Brothers and so on (Ezeani, Ogbonna, Ezemoyih \& Okonye, 2012, 5).

In order to preserve financial information integrity, the IASB issued the latest financial reporting conceptual framework in 2018, asserting the fact that financial statements are mainly aimed at providing decision-useful information to creditors, potential and present investors, as well as other stakeholders, when making credit, investment and allied resource allocation decisions, helping them assess the timing and amounts of the enterprise's prospective cash inflows and outflows. Furthermore, the chapter two of the framework specifies two principal threshold qualitative characteristics that these pieces of information must have in order to enhance decisionmaking, namely:

- fundamental (primary) characteristics, which include relevance and representational faithfulness, in addition to

- enhancing (secondary) characteristics, which comprise verifiability, timeliness, understandability and comparability.

\section{THE RATIONALE FOR THE STUDY}

Consequently, upon an exhaustive review of the extant literature on notable accounting scandals, like Enron, Tyco, WorldCom, HealthSouth and Xerox in the U.S, and the liquidation of the African International Bank (AIB), Cadbury and African Petroleum (AP) in Nigeria, a common observation is that financial statement preparers quite often flagrantly circumvent regulatory provisions and willfully manipulate accounting numbers, thus making nonsense of these qualitative characteristics of useful financial information. These unethical practices adversely affect the reliability and truthfulness of the financial information used to make investment decisions with dire implications for profitability and corporate sustainability (Odia \& Ogiedu, 2013, 45; Yahaya, 2014).

Particularly, these unethical practices have been thriving due to moral depravation and an utter disregard for ethical character traits in today's corporate world. Therefore, this research is aimed at assessing the chapter two of the IASB's 2018 qualitative characteristics of useful financial information and attempting to establish their conceptual linkage with ethical behavior within informal institutions, coupled with how their application to daily living may help accounting professionals (financial statement preparers) eschew fraudulent practices. The methodology for this research is based on Derrida's deconstruction theory.

Following this Introduction and Rationale for the study, the following sections of the paper are structured as follows: In Section 2, the extant literature and conceptual clarifications on the IASB's Conceptual Framework and biblical virtues are discussed. In Section 3, Derrida's deconstruction theory is extensively discussed as the research methodology adopted in order to establish conceptual linkages between the qualitative characteristics of useful financial information and biblical virtues. In Section 4, the research findings are exhaustively discussed and a model depicting the conceptual linkage is presented. In Section 5, the conclusion is given. 


\section{LITERATURE REVIEW}

\section{The significance and benefits of the global accounting standards harmonization}

The idea for the harmonization of global accounting standards arose from a quest for the synchronization of accounting practice throughout the European Union. However, the economic gains of convergence promptly encouraged the notion worldwide. Notably, the first set of the issued standards (originally referred to as the International Accounting Standards (IAS)) were released circa 1973 and 2001 by the International Accounting Standards Committee (IASC). On 1st April 2001, the newly constituted Board of IASB replaced the IASC, thus assuming responsibility for setting the International Accounting Standards. At its inaugural convention, the newfangled Board implemented the existing IAS and Standing Interpretations Committee standards (SICs). The IASB sustained the continuous development of the standards referring to the new standards as the International Financial Reporting Standards (IFRS). These sets of standards are fashioned as a mutual universal language for commercial transactions to aid in the understandability and comparability of company accounts across transnational boundaries. They are a fallout of rising international trade and shareholding principally important for multinational companies. Convergence to the globally recognized accounting standards (IFRS) enables comparability between companies operating in different countries. Therefore, the global accounting standards are aimed at removing restrictions to capital flows and expanding investment in markets. Equally, IFRS convergence promotes industrial growth, as complying with their provisions engenders investors' confidence and reduces the cost of raising foreign capital. The IFRS released by the IASB are currently being accepted and recognized as the foremost accounting information reporting standards globally. Presently, over a hundred nations are authorizing or mandating the IFRS implementation within their territories. It has become the most common and the most widely accepted financial reporting model throughout the world, given the fact that the countries of the Eurozone, New Zealand, Russia and Australia have instituted the legal frameworks that currently authorize the IFRS implementation within their respective jurisdictions. Equally, the Securities Exchange Commission (SEC) of the United States of America (USA) has endorsed the IFRS implementation without reconciling the United States Generally Accepted Accounting Principles (USGAAP) in the corporate reports prepared by foreign private enterprises, thereby availing foreign private enterprises discretionary privilege to choose between the IFRS and the USGAAP. The SEC suggested that USA enterprises should commence reporting under the IFRS from 2014, whereas a full conversion took place in 2016, contingent upon an entity's size, which action virtually encouraged the entire globe to one distinct, uniform accounting policy, i.e. the IFRS (Samir, 2003, 25; Srkant, 2005, 18; Olanrewaju, 2012, 13). Studies on the importance of transnational accounting practices have increased over years in response to the satisfaction of investors' demands, and expedite international business practices where there is a need to consider the fact that international accounting convergence is of a significant interest for investors, capital market regulators, governments and diverse stakeholders who utilize the accounting information of public enterprises, thus accentuating the strategic role of accounting as a fiscal tool for several economic agents. The advantages of such global accounting convergence rests on its ability to lessen adverse effects emanating from different accounting practices in diverse countries (Hati \& Rakshit, 2002, 34; Bala, \& Ibrahim, 2017, 75). Hence, the introduction of the IFRS for listed companies in many countries could globally be regarded as a radical regulatory innovation to the history and practice of the accountancy profession.

In their paper espousing the significance of the firstrate accounting standards, H. Daske and H. Gunther $(2006,464)$ emphasized the fact that the accounting standards harmonization was germane to the delivering of the reliable information rooted in honest financial reporting. He enumerates the three major 
criteria the international standards have to have in order to be accepted, namely:

- The standards have to incorporate the core sets of the accounting declarations that constitute a generally accepted and comprehensive accounting basis.

- The standards should be of a high quality and have to guarantee transparency and comparability by providing full disclosure. Shareholders should be capable of implicitly analyzing performance across financial years and companies.

- The standards have to be meticulously interpreted and globally enforced by regulators and auditors by their insisting on the painstaking application and interpretation of those standards. If not so, the transparency and comparability objective of the mutual standards will be defeated.

\section{The IASB conceptual framework}

The IASB Conceptual Framework for Financial Reporting can be described as the main document that stipulates the concepts and objectives which guide the presentation and preparation of financial reports. The framework is a comprehensive structure of the concepts that emanate from an objective, while the objective recognizes the financial reporting rationale. The concepts offer a direction towards the recognition of the limits of financial reporting, a choice of transactions and economic activities to be recognized and measured (or disclosed), in addition to the formats for their summarization and reporting (FASB, 2006, 2-5; 2010, 3)

The core purpose of the Framework includes (IASB, 2018):

- assistance in reviewing the existing standards and the formulation of future IFRS by spelling out the fundamental concepts;

- fostering the synchronization of accounting standards and regulation by decreasing the number of allowable marginal accounting treatments;
- assistance for the preparers of published financial statements applying the IFRS, especially with regards to the handling of the business events for which an accounting standard is yet to be formulated.

Its precursor, the Framework for the Preparation and Presentation of Financial Statements, was issued in 1989. While, on the one hand, the IASB issued an improved version in 2010, which was referred to as the Conceptual Framework for Financial Reporting, this version was notably quite incomplete given the fact that a few chapters and concepts were omitted, the latest and the most comprehensive Framework issued in 2018, on the other, includes a total of eight chapters itemized below:

- Chapter One: The Objective of General-Purpose Financial Reporting

- Chapter Two: The Qualitative Characteristics of Useful Financial Information

- Chapter Three: Financial Statements and the Reporting Entity

- Chapter Four: The Elements of Financial Statements

- Chapter Five: Recognition and Derecognition

- Chapter Six: Measurement

- Chapter Seven: Presentation and Disclosure

- Chapter Eight: The Concepts of Capital and Capital Maintenance

Bearing in mind the fact that this research is principally focused on assessing the conceptual linkages between the Qualitative characteristics of useful financial information and ethical conduct in informal institutions, chapter two of the conceptual framework constitutes the major basis of analysis hence an exhaustive discussion of its attributes is necessary to enrich our understanding of the background of the study. 


\section{The qualitative characteristics of useful financial information}

Qualitative characteristics refer to the attributes necessary for accounting information to serve as the key supporting function in the usefulness of decisions. These are the characteristics and qualities which the preparers of financial statements have to imbibe with a view of making accounting information worthwhile for users. According to the FASB $(2010,15)$, reported accounting information aimed at facilitating investment decisions should have certain features or normative standards, the informational attributes of decision-useful financial statements recognized by the FASB in its Concept No. 2 Qualitative Characteristics of Accounting Information, and slightly modified and accepted in the IASB Framework. Chapter Two, entitled the Qualitative Characteristics of Useful Financial Information, is presented in Figure 1.

The chapter two of the IASB Conceptual Framework identifies the two kinds of the qualitative characteristics required for financial information to be decision-useful:
- fundamental (primary), and

- enhancing (secondary).

The fundamental (primary) qualitative characteristics of financial information include the following:

- relevance, which refers to the ability of financial information to significantly influence users' economic decisions. Financial information is deemed to be relevant when it has a confirmatory value, a predictive value, or both these values. Materiality is akin to relevance.

- faithful representation, which implies that information is deemed to be faithfully represented when being error-free, complete and neutral.

- The enhancing (secondary) qualitative characteristics of financial information include the following:

- comparability, which implies the fact that information should be similar between different entities or different time periods;

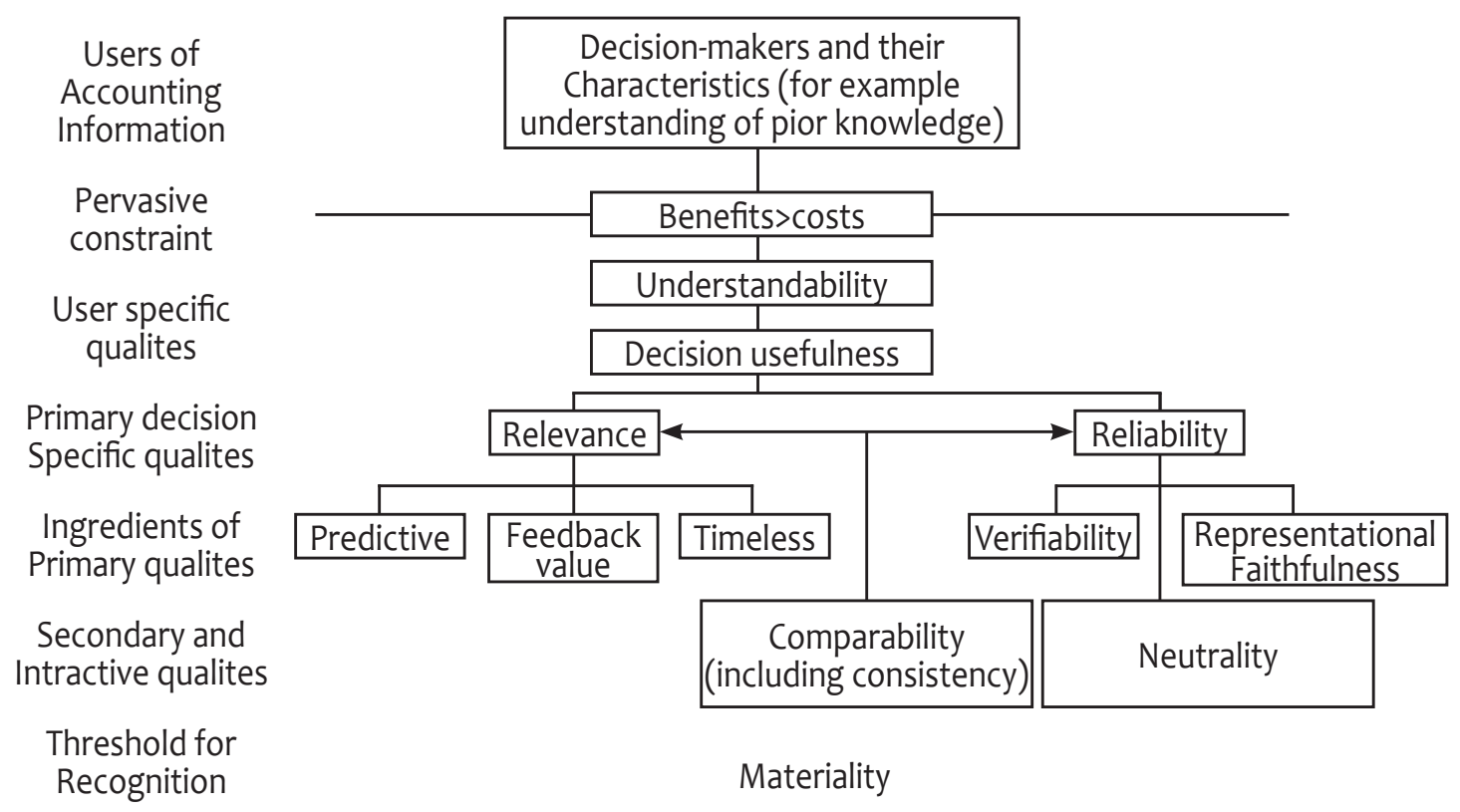

Figure 1 A Hierarchy of Accounting Qualities 
- verifiability, which implies that knowledgeable and independent witnesses should be capable of authenticating such information;

- timeliness, which connotes the availability of information as and when required in order to influence the user's economic decisions, and

- understandability, which implies that information should concisely and clearly be categorized and presented.

\section{Differences between FASB 2006 and IASB 2018 Conceptual Framework with respect to the qualitative characteristics of accounting information}

Based upon the discussion in the preceding section, it can be observed that, although the FASB 2006, SFAC No. 2 (as depicted in Figure 1) and the chapter two of the IASB 2018 Conceptual Framework are primarily focused on the qualitative characteristics of accounting information, there are obvious differences in their respective contents with respect to the elements of financial statements and the primary or fundamental qualities, while the contents of the IASB 2018 Conceptual Framework consist of relevance and faithful representation, and those of the FASB 2006 consist of relevance and reliability. Observed from the point of view of the requirements of the fundamental qualities, differences are equally present. In IASB
2018, relevance consists of the predictive value and the confirmatory value, and in FASB 2006, it consists of the predictive value, the feedback value and timeliness. Additionally, IASB 2018 faithful representation consists of completeness, neutrality and the absence of an error. In FASB 2006, however, it is named reliability and consists of verifiability, representational faithfulness and neutrality. Perceived from the point of view of the enhancing qualities, it is also different. In IASB, it consists of comparability, verifiability, timeliness and understandability. Remarkably, the IASB 2018 Financial Reporting Conceptual Framework represents a comprehensive and updated document aimed at enhancing the qualitative characteristics of financial statements, bearing in mind the fact that the same incorporates an innovation regarding the interpretation of the notion of fair reporting and presentation, which connotes the essence of decision-useful financial statements.

The differences between the FASB 2006 and IASB 2018 conceptual frameworks is are described in Table 1.

\section{The nexus between biblical virtues and ethical behavior constructs}

Virtue is defined by Webster's dictionary as "conformity to the standard of right: morality. Moral excellence; beneficial quality, strength and courage, and a capacity to act: potency". Viewing this definition from a biblical standpoint, R. J. Krejcir (1991,

Table 1 The differences between FASB 2006 and IASB 2018 in the qualitative characteristics of accounting information

\begin{tabular}{|c|c|c|c|c|}
\hline \multirow{2}{*}{$\begin{array}{l}\text { Description } \\
\text { Primary/fundamental } \\
\text { quality }\end{array}$} & \multicolumn{2}{|c|}{$\begin{array}{l}\text { FASB qualitative characteristics of accounting } \\
\text { information }\end{array}$} & \multicolumn{2}{|c|}{$\begin{array}{l}\text { IASB qualitative characteristics of useful } \\
\text { financial information }\end{array}$} \\
\hline & Relevance & Reliability & Relevance & $\begin{array}{l}\text { Faithful } \\
\text { representation }\end{array}$ \\
\hline $\begin{array}{l}\text { Ingredients of } \\
\text { fundamental qualities }\end{array}$ & $\begin{array}{l}\text { - Predictive value } \\
\text { - Feedback value } \\
\text { - Timeliness }\end{array}$ & $\begin{array}{l}\text { - Verifiability } \\
\text { - Representational } \\
\text { faithfulness } \\
\text { - Neutrality }\end{array}$ & $\begin{array}{l}\text { - Predictive value } \\
\text { - Feedback value }\end{array}$ & $\begin{array}{l}\text { - Completeness } \\
\text { - Neutrality } \\
\text { - Error-free }\end{array}$ \\
\hline Enhancing qualities & \multicolumn{2}{|c|}{ Comparability, consistency } & \multicolumn{2}{|c|}{$\begin{array}{l}\text { Comparability, verifiability, timeliness, } \\
\text { understandability }\end{array}$} \\
\hline
\end{tabular}

Source: Kieso, Weygandt \& Warfield, 2007; Kieso, Weygandt \& Warfield, 2011 
2001) defines virtue as the tendency to be blameless, prompted by a deliberate will to act right from the point of the word of God, in addition to personal responsibility. It involves compassion, honesty, integrity and endearment, which epitomizes the essence of the biblical character (modesty, strength, right standards, purity and courage, all complete in excellence). He notes that virtue is acquired through faith in and obedience to Christ, which occur in true repentance. Furthermore, by espousing the inimitable positive effects of constant meditation on biblical virtues, Apostle Paul summarily concludes in the Philippians Chapter 4 Verse 8: "Finally, brethren, whatever things are true, whatever things are noble, whatever things are just, whatever things are pure, whatever things are lovely, whatever things are of good report, if there is any virtue and if there is anything praiseworthy - meditate on these things." (The Holy Bible, KJV). Ostensibly, the biblical definition of virtue infers the attitudes that are just (fair), noble, pure (holy living), true (the truth), lovely (as Christ is), and the character of good report (noble acts towards God and Man). However, as already mentioned herein, these ethical character traits are scarce in today's corporate world as corruption, greed and malfeasance in the workplace have become rampant, immoral and the unethical abuse of office has become commonplace amongst business executives in an effort to mitigate their untoward impact on businesses. The government on its part has enacted several legislations, such as the 2002 Sarbanes-Oxley Act, which was a direct reaction to the Enron accounting scandal in the United States of America, so as to assist in shielding shareholders from fraudulent financial reporting by companies.

\section{The theoretical framework}

This study is anchored in the agency theory of accounting research, which underscores the stewardship reporting responsibility of managers (agents) to the shareholders (owners) of the enterprise via corporate reports geared towards proffering valuedriven, reliable and relevant accounting information suitable for financial analysis and investment decisions. This theory presupposes that principals (shareholders) are those who own the company, whereas agents (managers) are those controlling it. However, this separation of the company ownership from company control will create agency problems, whereas a conflict of interest might arise in firms in situations when managers' (agents') personal interests override their obligations to comply with the principalagent contract stipulating the maximization of shareholders' wealth (Sheikh, Khan, Iqbal \& Ahmed, 2012, 243). However, while financiers (principals) need managers' specialized skills to create returns on invested capital, management ultimately depends on principals for the financial structuring of the business they supervise, thus needing an approval from them. Creating complexities in the agency relationship in that manner, among which, foremost, is the fact that the management is more informed about corporate numbers than the principals (information asymmetry), this insider information might be fraudulently exploited, which invariably manifests in unethical and criminal conduct, which occasioned several accounting scandals involving financial statement manipulation (earnings management/ creative accounting) by the trustworthy executives of corporate entities, as was the case in the Enron, WorldCom and Lehman Brothers corporate scandals.

\section{RESEARCH METHODOLOGY}

In this research, Derrida's deconstruction theory was employed, adapted from M. Al-Fayyadl (2005) and B. Stocker (2006), so as to conduct a diagnostic content analysis of the chapter two of the IASB 2018 Financial Reporting Conceptual Framework, aimed at ascertaining the conceptual linkages between the qualitative characteristics of useful financial information and the ethical behavior constructs inherent in the Bible. According to B. Stocker (2006), deconstruction equally subsists within the "difference", but from varied perspectives, and the core of such "difference" unto differences. However, they have essentially similar content (hidden truths behind an obvious reality). However, restating Derrida's deconstruction theory, M. Al-Fayyadl (2005) espoused that deconstruction entails inducement not to gloss over the sole truth that we accept as 
true, but there are multiple realities that suit various perspectives of the thought process, the principal notion of deconstruction theory being related to repetition and otherness happening simultaneously, which implies that the truth can be perceived from another point of view or from a different perspective.

\section{RESEARCH FINDINGS AND DISCUSSIONS}

\section{Deconstructing the Biblical Origins of Contemporary Agency Theory}

Financial reporting is the primary offshoot of stewardship accounting, whose origins go back to ancient times, when landlords (present-day principals, business owners or shareholders) listened to the report or accounts of serfs/servants (presentday agents, managers, and/or directors) on how they had managed the affairs of the business in order to ascertain whether they had made a profit or a loss. That report was usually presented at the close of a voyage or trading period, usually on an annual basis (the present-day Annual General Meeting AGM). In the Bible Book of Luke 19, verses 12-22, and Matthew 25, verses 14-39, Jesus gives a parable of noble man (the landlord), who journeyed to a far country, bequeathing his goods (money) to his ten servants in order for them to trade. Upon his return, he required them to give him an account of the goods having been entrusted to them. Those who made a profit were rewarded, whereas those who made a loss were sanctioned or punished. The parable describes the ancient practices, the way how it was then, and is arguably what has metamorphosed into modern-day agency theory in accounting research, in which the owners of the entity (shareholders) entrust the control and management of their company to managers and directors, who accordingly act as agents on their behalf (Eisenhardt, 1989; Donaldson \& Davis, 1991).

Biblical ethical constructs deconstructed from the qualitative characteristics of useful financial information
As already said, the analysis of this research centers on the chapter two of the IASB 2018 Conceptual Framework on the qualitative characteristics of useful financial information.

By utilizing Derrida's deconstruction theory, the analysis of the fundamental (primary) qualitative characteristics of financial information, viz. relevance and faithful representation, as the attributes that enable accounting information suitable for decisionmaking was conducted. Relevance presupposes that accounting information should have the ability to significantly influence users' economic decisions. Financial information is considered as relevant when it has confirmatory and predictive values. (Kieso et al, 2011, 44; Ekasari, 2012a, 310)

Faithful representation implies that a piece of information is deemed to be error-free, complete and neutral, accurate, fair and objective.

Juxtaposing these attributes with biblical injunctions and admonitions from the LORD GOD, Jesus, the prophets and the apostles, there is a clear conceptual similarity. Some examples will suffice. Firstly, in his first epistle to the Corinthians Chapter 4 Verse 2, Paul the Apostle states that "moreover it is required in stewards that a man be found faithful". Equally, in Isaiah, Chapter 8 Verse 2, the prophet records how he took faithful witnesses including Uriah and Zachariah, who were both priests, to take a record of the events to come.

Furthermore, in Chapter 25, Verse 15, Deuteronomy harps on the need for standard weights and measures, by quoting as follows: "but thou shalt have a just weight, a perfect and just measure shalt thou have: that thy days may be lengthened in the land which the LORD thy GOD giveth thee", which was corroborated by the Proverbs Chapter 16 Verse 11, "a just weight and balance are the LORD's all the weights of the bag are his work". The Holy Bible (the king James's version of it). The scriptures above allow us to conveniently deduce the time-honored ethical constructs of objectivity and fairness, the accuracy of facts, and neutrality.

Secondly, the deconstruction of the biblical virtues from the enhancing (secondary) qualitative 
characteristics of financial information is discussed below:

Comparability: Comparability implies that information should be similar between different entities or different time periods, which enables the matching of accounting information pertaining to one entity with similar information in another entity. From the biblical perspective, this accounting concept teaches us humility, which ultimately spurs motivation. By comparing our business enterprise with other enterprises in the same industry, a better understanding of our current performance ratings, whether favorable or adverse (variance analysis) is obtained, thereby making necessary adjustments. This process demands humility (Ekasari, 2012b) In Peter Chapter 5 Verse 5, the Bible admonishes the younger to submit to their elders and be covered with humility because GOD resists the proud and gives more grace to the humble.

Verifiability: Verifiability is implicative of the fact that knowledgeable and independent witnesses should be capable of authenticating a piece of information, which ensues when independent observers apply the same techniques and obtain comparable results (Kieso et al, 2011). Verifiability ensures data accuracy and entrenches trust, honesty and responsibility, deconstructing this attribute from the biblical standpoint. In the first Thessalonians Chapter 2 Verse 10, Paul the Apostle says "ye are witnesses and God also, how holily and justly and unblameably we behaved ourselves among you that believe", this being further buttressed by Samuel the Prophet at the twilight of his tenure as a judge in ancient Israel, who so declared in Samuel Chapter 12 Verse 3: "Behold here I am: witness against me before the LORD, and before his anointed: whose ox have I taken? Or whose ass have I taken? Or whom have I defrauded? Whom have I oppressed? Or of whose hand have I received any bribe to blind my eyes therewith? And I will restore it to you." From this scriptural declaration, it is possible to deduce open accountability and public trust.

Timeliness: Timeliness connotes the availability of information as and when required in order to influence users' economic decisions. It implies that information are made accessible to decision-makers at the right time so as to exert a significant influence on the decision-making process. Timeliness expects us to document accounting transactions as they occur. Discipline and diligence, exemplified in the Proverbs Chapter 22 Verse 29: "Seest thou a man diligent in his business? He shall stand before kings; he shall not stand before mean men," are the biblical conceptual equivalence of this virtue.

Understandability: Understandability indicates the fact that accounting information should concisely and clearly be categorized and presented so as to help users make economic decisions. Financial information should be presented in trust and honesty, and responsibly. Biblically, it is possible to deconstruct the virtue of equality from this concept, because if two entities demonstrate an equal understanding, that implies that they share the same information.

In Figure 2, a conceptual model summarizing the linkages between the IASB qualitative characteristics of useful financial information and the ethical behavior constructs inherent in the Bible are presented.

\section{CONCLUSION}

This research study is aimed at assessing the conceptual linkages between the IASB qualitative characteristics of useful financial information and ethical behavior within informal institutions by applying Derrida's deconstruction theory in order to conduct a diagnostic content analysis of the chapter two of the Framework. The obtained findings are indicative of a significant positive relationship between the qualitative characteristics of useful financial statements, as advocated in the IASB 2018 Financial Reporting Framework, on the one hand, and ethical behavior within informal institutions, on the other. The study observed the striking conceptual linkages between the fundamental and enhancing qualitative attributes and the biblical ethical behavior constructs, such as objectivity, equity/fairness, accuracy, neutrality, humility, trust, 


\section{STEWARDSHIP ACCOUNTING}

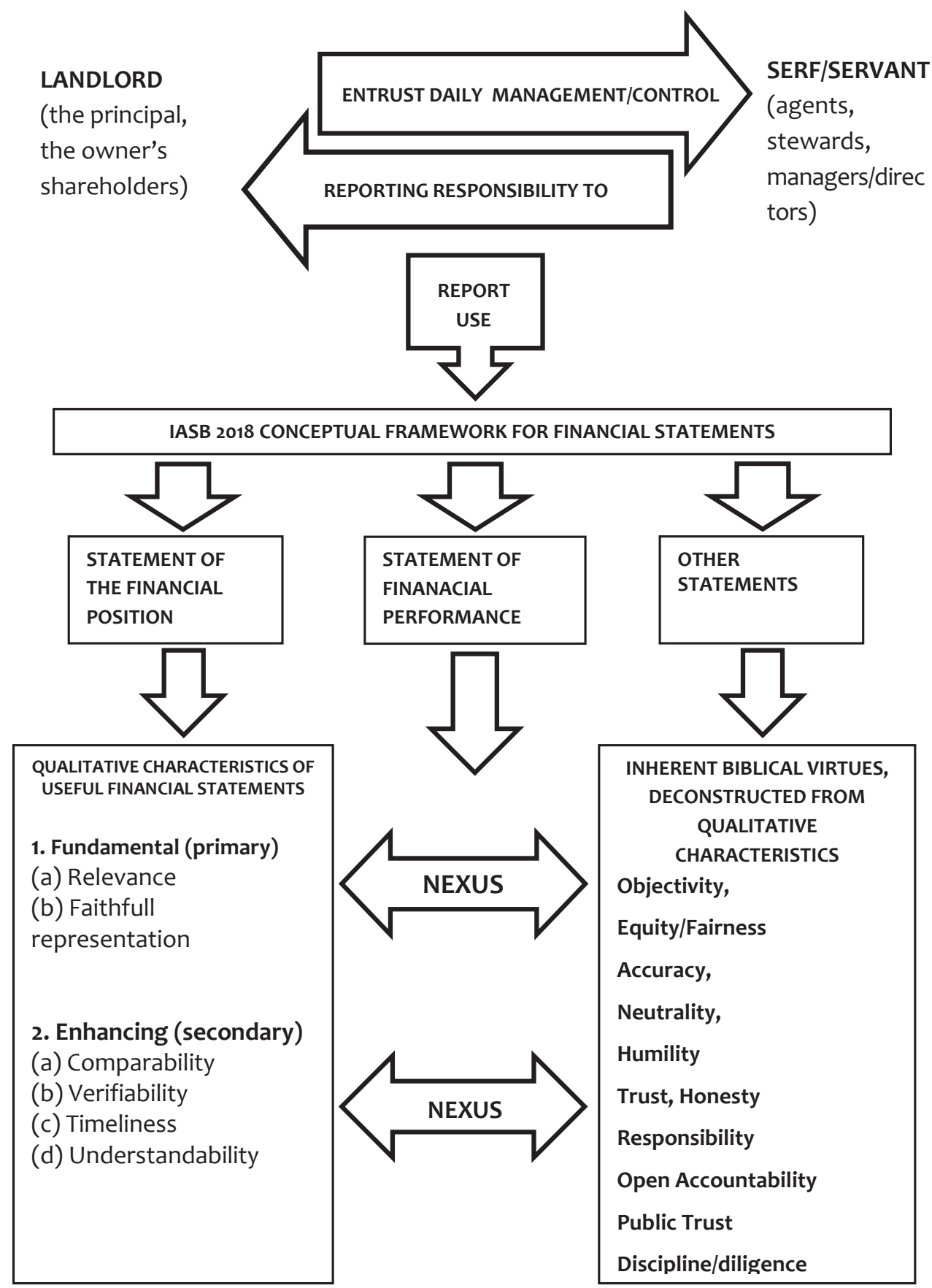

Figure 2 The conceptual model depicting the linkages between the IASB qualitative characteristics of useful financial information and ethical behavior constructs 
honesty, responsibility, open accountability, public trust, discipline and diligence. These results were corroborated by T. R. Schatzi $(2005,481)$ and K. Ekasari (2012b), who noted that the enforcement of compliance on regulatory provisions and accounting standards appeals to practitioners' will, which they can flout under the guise of applying discretionary judgements; biblical injunctions, however, appeal to practitioners' inner consciousness (the spirit/soul dimension). Hence, biblical ethical behavior forms an inimitable fragment of spiritual doctrines and norms, whose adherents are expected to conform with the beliefs, desires and emotions that ultimately culminate in desirable actions. Bearing in mind the emerging spiritual accounting philosophy, it can be concluded that there is a need for them to appeal to the moral/ ethical consciousness of the preparers of accounting information for the purpose of preserving qualitative attributes. Thus, the following is recommended:

- The accounting curriculum at both tertiary and professional levels should be re-evaluated and enriched with these biblical ethical constructs in order to inculcate them into students prior to their entering the accounting profession, which will go a long way towards instilling forthrightness and propriety in the treatment of transactions and the preparation of decision-useful financial statements.

- Beyond their inclusion in the curriculum, these biblical ethical constructs should be integrated into accounting pedagogy (the teaching-learning process), given the fact that doing so will effectively persuade students' cognitive domain to positively influence the affective domain, thereby producing intellectually sound and morally balanced accounting professionals, who will carry out duties assigned to them with a high sense of moral/ethical responsibility.

Furthermore, future research studies could be conducted so as to deconstruct the biblical/spiritual virtues from the other chapters of the IASB 2018 Financial Reporting Conceptual Framework, which will further expand the knowledge frontiers of accountancy pedagogy, promote moral/ethical consciousness amongst accounting practitioners, simultaneously significantly contributing to the deepening of the emerging spiritual accounting philosophy.

\section{REFERENCES}

Al-Fayyadl, M. (2005). Derrida. Published by LKiS Pelangi Aksara Yogyakarta.

Bala, H., \& Ibrahim, I. (2017). Monitoring characteristics and financial reporting quality of listed conglomerates firms in Nigeria. Journal of Accounting Research and Practice, 3(2), 75-93.

Daske, H., \& Gunther, H. (2006) International financial reporting standards and expert perception of disclosure quality. Abacus, 42(3/4), 461-498. doi.org/10.1111/j.14676281.2006.00211.x

Donaldson, L., \& Davis, J. H. (1991). Stewardship theory or agency theory: CEO governance and shareholder returns. Australian Journal of Management, 16(1), 49-65. doi. org/10.1177/031289629101600103

Ebiaghan, O. F. (2018). Assessment of the comparative ability of Accounting Bases in predicting future cash flows: Evidence from Nigeria. Trends Economics and Management Faculty of Business and Management, 12(32), 35-48. doi.org/10.13164/trends.2018.32.35

Eisenhardt, M., K. (1989). Agency theory: An assessment and review. The Academy of Management Review, 14(1), 5774. doi:10.2307/258191

Ekasari, K. (2012a). Portraying Accounting in spirituality perspesctive. Review of Integrative Business \& Economics Research, 1(1), 304-315.

Ekasari, K. (2012b, June). Exploring Spirituality Values in Accounting. Paper presented at the SIBR-Thammasat Conference on Interdisciplinary Business and Economics Research, Bangkok.

Ezeani, N. S., Ogbonna, M. I., Ezemoyih, E. M., \& Okonye, E. C. (2012). The effect of creative accounting on the job performance of accountants (auditors) in reporting financial statement in Nigeria. Kuwait Chapter of Arabian Journal of Business and Management Review, 1(9), 3-12. 
Financial Accounting Standards Board (FASB). (2006). Conceptual framework for reporting objectives of financial reporting and qualitative characteristics of decision-useful financial reporting information. FASB Website Terms and Conditions.

Financial Accounting Standards Board (FASB). (2008). Statement of Financial Accounting Concept No. 2, Qualitative of Accounting Information. Stamford: FASB.

Financial Accounting Standards Board (FASB). (2010). Conceptual framework for financial reporting: The objective of financial reporting and qualitative characteristics of useful financial information. FASB Website Terms and Conditions.

Hati, W. J., \& Rakshit, D. FASB Website Terms and Conditions. (2002). Integrating accounting standards -A step towards harmonization. Management accountant, ICWAI, 4(2), 32-41. Retrieved March 18, 2020, from http:// www.iasplus.com.

Kieso, D. E., Weygandt, J. J., \& Warfield, T. (2007). Intermediate Accounting. Hoboken, New Jersey: John Wiley and Sons.

Kieso, D. E., Weygandt, J. J., \& Warfield, T. (2011). Intermediate Accounting, IFRS Edition. Hoboken, New Jersey: John Wiley and Sons.

Krejcir, R. J. (1991, 2001). Why virtue is important and needed. Into Thy Word Ministries. Retrieved March 18, 2020, from www.intothyword.org.
Odia, J. O., \& Ogiedu, K. O. (2013). Corporate governance, regulatory agency and creative accounting practices in Nigeria. Mediterranean Journal of Social Sciences, 4(3), 5566. doi:10.5901/mjss.2013.v4n3p55

Olanrewaju, O. O. (2012). IFRS PAL-Handy approach (international financial reporting standards) with real life questions and answers. Lagos. Dimkem Publications.

Samir, M. S. (2003). Harmonisation of Accounting Standards. Chartered Accountant, ICAI, January, 4(2), 23-32

Srikant, S. (2005). Accounting Standards - will the World be talking same language? Chartered Accountant, ICAI, February 3(1), 15-22

Schatzki, T. R. (2005). Peripheral Vision: The sites of organizations. Organization Studies, 26(3), 465-484. doi. org/10.1177/0170840605050876

Sheikh, J. Khan, M, Iqbal, W., \& Ahmed, W. S. (2012). Examination of theoretical and empirical studies on firm's performance in relation to its board size: A study of small and medium size public firms. Journal of Management Research, 4(2), 242-254. doi:https://doi.org/10.5296/jmr. v4i2.1504

Stocker, B. (2006). Routledg Philosophy Guidebook to Derrida on Deconstruction. Abingdon, UK: Routledge.

The Holy bible, Authorized King James Version.

Yahaya, K. A. (2014, September). Creative Accounting Practices: Ethical Challenges In Nigerian corporate Environment. Paper presented at the Development Finance Conference, At Dubai.

$$
\begin{array}{r}
\text { Received on } 19^{\text {th }} \text { March 2020, } \\
\text { after revision, } \\
\text { accepted for publication on } 17^{\text {th }} \text { August } 2020 . \\
\text { Published online on } 19^{\text {th }} \text { August } 2020 .
\end{array}
$$

Ebiaghan Orits Frank is a scholar at the Department of Accounting and Finance of the Faculty of Social Sciences of Delta State University of Abraka, Nigeria. He earned his PhD in accountancy from the Nnamdi Azikiwe University of Awka. He has broadly published and his research interest covers financial reporting, financial policy evaluation and accounting theory. 


\title{
KONCEPTUALNE VEZE KVALITATIVNIH KARAKTERISTIKA KORISNIH FINANSIJSKIH INFORMACIJA I ETIČKOG PONAŠANJA KAO NEFORMALNIH INSTITUCIJA
}

\author{
Ebiaghan Orits Frank \\ Faculty of the Social Sciences, Delta State University, Abraka, Nigeria
}

Ovo istraživanje ima za cilj procenu konceptualnih veza kvalitativnih karakteristika korisnih finansijskih informacija, definisanih od strane Odbora za međunarodne računovodstvene standarde (OMRS), i etičkog ponašanja kao neformalnih institucija. Deridina teorija dekonstrukcije se koristi za sprovođenje dijagnostičke analize sadržaja konceptualnog okvira za finansijsko izveštavanje iz drugog poglavlja MRS iz 2018. Saznanja, do kojih se došlo tokom izvođenja ove studije, ukazuju na postojanje izuzetno važnih konceptualnih veza između fundamentalnih (primarnih) kvalitativnih karakteristika i kvalitativnih karakteristika kojima se poboljšava kvalitet finansijskih izveštaja (sekundarnih kvalitativnih karakteristika), s jedne, i etičkih normi, kao što su objektivnost, pravednost/pravičnost, tačnost, neutralnost, poniznost, poverenje, iskrenost, odgovornost, otvorena pravna odgovornost, javno poverenje, disciplina i revnost, s druge strane. Kao posledica toga, u studiji se daju preporuke za uključivanje navedenih etičkih normi i podučavanje studenata tim konstruktima, kroz uključivanje istih u kurikulume tercijarnih i stručnih računovodstvenih programa, kako bi se obrayovali pouzdani intelektualci i moralno uravnotežene računovođe, koji će pripremati i predočavati finansijske izveštaje korisne za donošenje odluka, uz izraženi osećaj za moralnu i etičku odgovornost.

Ključne reči: računovodstvene informacije, Biblija, etičko ponašanje, Konceptualni okvir OMRS 2018, kvalitativne karakteristike

JEL Classification: M400, M410 